\title{
First record of Pyramodon lindas (Markle and Olney, 1990) (Ophidiforms: Carapidae) from Indian Seas
}

\author{
K. K. Joshi ${ }^{1 *}$, K. Kannan², P. U. Zacharia ${ }^{1}$, J. A. Johnson ${ }^{3}$ and Gimy George ${ }^{1}$
}

\begin{abstract}
Background: The present report is the first record of the Pyramodon lindas (Markle and Olney, Bull Mar Sci 47: 269-410, 1990) from India waters. A specimen of Pyramodon lindas measuring $483 \mathrm{~mm}$ total length was obtained from Tuticorin of Gulf of Mannar which is the largest specimen of so far recorded.

Results: The Pyramodon lindas measured $483 \mathrm{~mm}$ in TL, $85 \mathrm{~mm}$ in Head length, $18.1 \mathrm{~mm}$ in snout length. Body elongate, compressed to round and eel like, supramaxilla absent, anal fin origin advanced. The specimen was deposited in the National Biodiversity Museum at the Central Marine Fisheries Research Institute, Kochi (GB.28.3.3.1) Detailed mophometric and meristic characters described and discussed.

Conclusion: The Pyramodon lindas reported in the present study makes the total species reported from India as four in family Carapidae. The other reports were Carapus homei (Richardson, 1846), Pyramodon punctatum (Regan, 1914), Carapus margaritiferae (Rendahl, 1921) Brotula multibarbata Temmink \& Schlegel, 1846 Antennarius hispidus (Bloch \& Schneider, 1801).
\end{abstract}

Keywords: First record, Pyramodon lindas, Carapidae, Indian Seas, Gulf of Mannar

\section{Background}

Gulf of Mannar is known to harbour over 3600 species of flora and fauna, making it one of the richest coastal regions in Asia. This region is also home to over 450 species of fish, 79 species of crustaceans, 108 species of sponges, 260 species of mollusks and 100 species of echinoderms. Three species in the family Carapidae, Carapus homei (Richardson, 1846) Pyramodon punctatum (Regan, 1914) Carapus margaritiferae (Rendahl, 1921) (Mahadevan, 1961) was reported from Indian seas. The genus name Pyramodon was described by Smith and Radcliffe in 1913.

They are eel like with large single vomerine fang and pelvic fin rays present. Dorsal fin originates anterior or directly over anal fin origin. They occur in shallow to deep waters of continental shelves and slopes in tropical water of Indo-west Pacific. The genus Pyramodon is mainly contains four species namely Pyramodon lindas, Pyramodon

\footnotetext{
* Correspondence: joshyguru@gmail.com

${ }^{1}$ Central Marine Fisheries Research Institute (CMFRI), Post Box 1603, Ernakulam

North P.O., Kochi 682018, Kerala, India

Full list of author information is available at the end of the article
}

parini, Pyramodon punctatus and Pyramodon ventralis (Strasburg 1965, Gosline 1960, Trott 1981, Robins and Nielsen 1970, Cohen \& Nielsen 1978, Nielsen, et al. 1999). The present study is intended to discuss morphology of Pyramodon lindas, Black edge pearl fish from Gulf of Mannar, India. The length of Pyramodon lindas (Total length $483 \mathrm{~mm}$ ) is more than the reported maximum length of $36.0 \mathrm{~cm}$ TL male/unsexed Western Pacific (Markle and Olney, 1990).

\section{Materials and methods}

A single specimen of fish was collected from Tuticorin fish harbour, 23 February, 2010. The specimen was caught by using Mechanized vessel boat, Trawler net. All counts and measurements were taken according to those methods described in Markle and Olney 1990. The specimen was identified as Pyramodon lindas based on morphometric and meristic characters described by Markle and Olney 1990. The morphometric measurements were taken to the nearest $\mathrm{mm}$ using a digital vernier caliper following Markle and Olney 1990. All measurements and count of the present specimen are 
Table 1 Morphometric characters of Pyramodon lindas from Tuticorin, Gulf of Mannar (current study)

\begin{tabular}{lll}
\hline Morphometric Characters & Measurements (mm) & As \% HL \\
\hline Total length & 483 & \\
Head length (HL) & 85 & 0.21 \\
Snout length (SNL) & 18.1 & 0.57 \\
Body depth (BD) & 48.2 & 0.22 \\
Pre orbital length(POB) & 18.3 & 0.69 \\
Post orbital length (PSB) & 58.6 & 0.13 \\
Eye diameter (ED) & 11.4 & 0.41 \\
Upper jaw length (UJL) & 35.1 & 0.45 \\
Lower jaw length (LL) & 37.9 & 0.20 \\
Dorsal fin length (DL) & 17.4 & 0.47 \\
Dorsal fin base length (DBL) & 39.8 & 0.53 \\
Pectoral fin length (PFL) & 45.3 & 0.17 \\
Pectoral fin base length (PBL) & 14.1 & 1.12 \\
Pre Pelvic fin length (PPL) & 95.2 & 0.41 \\
Pelvic fin length (PL) & 35.0 & 0.07 \\
Pelvic fin base length (PLB) & 5.7 & 0.83 \\
Pre dorsal length (PDL) & 70.6 & 1.12 \\
Pre anal length (PAL) & 95.3 & 1.16 \\
Snout to anus length (STA) & 98.7 & 0.17 \\
Anal fin length (AL) & 14.2 & 3.06 \\
Anal fin base length (ABL) & 260 & \\
\hline
\end{tabular}

given in Table 1. The specimen was deposited in the $\mathrm{Na}$ tional Biodiversity Museum at the Central Marine Fisheries Research Institute, Kochi (GB.28.3.3.1)

\section{Results}

Systematics

Kingdom Animalia

Phylum Chordata

Class Actinopterygii

Order Ophidiiforms

Family Carapidae Jordan and Fowler (1902)
Subfamily Pyramodontinae

Genus Pyramodon Smith and Radcliffe, 1913

Species Pyramodon lindas (Markle \& Olney, 1990) (Fig. 1).

\section{Diagnosis}

Body elongate, compressed to round and eel like, supramaxilla absent, anal fin origin advanced.

\section{Fin formula}

$\mathrm{D}_{30}$ (dorsal fin rays to $31^{\text {st }}$ vertebra) $53, \mathrm{P}_{1}$ (pectoral fin rays) $23, A_{30}$ (anal-fin rays to $31^{\text {st }}$ vertebra) 50 , DRAO (dorsal fin rays to anal origin) 16 and the data of the Holotype (AMS 1.22825-011) was 50, 22, 50 and 13 respectively (Markle and Olney, 1990).

\section{Description}

Eel-like, moderate to relatively deep body depth; a large single vomerine fang; pelvic fin rays present; swim bladder large, filling visceral cavity and extending past anus; dorsal and anal fin radials robust and elongate; dorsal fin anterior or directly over anal fin origin; lacking rocker bone, cardiform teeth, and intrinsic swim bladder constrictions or tunic ridges Margins of dorsal and anal fins edged in black over entire length; head and body generally unpigmented. Larvae not extremely elongate with vexillum adjacent to first dorsal fin ray, with large head and deep body and enlarged premaxillary cartilage. The morphometric data and data expressed as percentage of head length are given in Table 1 . The comparison of data with the holoptype is given in the Table 2. The size varies from 229 to $360 \mathrm{~mm}$ in TL. This is the largest carapid known to date. It has 21-25 pectoral fin rays. Pectoral fin length is relatively short. The tips of its rays falling $0-13 \mathrm{~mm}$ short of the posterior end of the swim bladder.

\section{Colour}

Lightly coloured with the exception of the dorsal and anal fin margins which are quite dark head and body are generally unpigmented. There is an unpigmented patch on the cheek that over lies the adductor mandibulae.

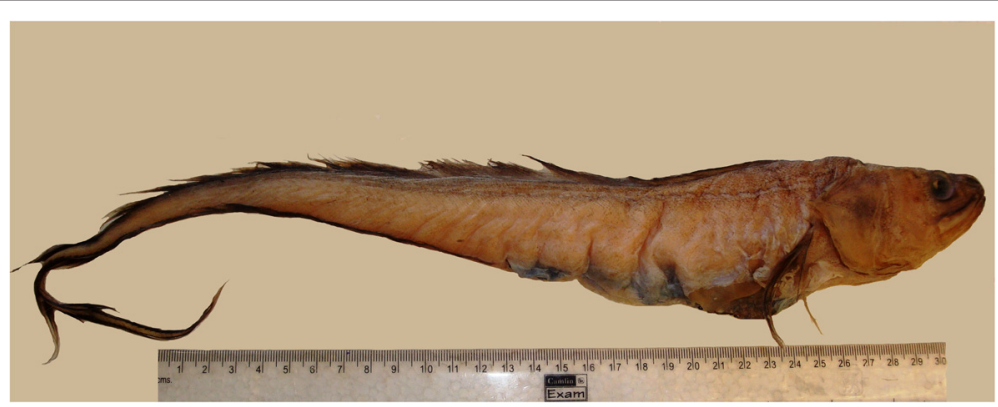

Fig. 1 Lateral view of the specimen Pyramodon lindas (Markle \& Olney, 1990) collected from Indian sea 
Table 2 Comparison of Pyramodon lindas with holotype and paratypes

\begin{tabular}{|c|c|c|c|c|}
\hline Parameter & Markle and Olney 1990 & Holotype (mm) AMS 1.22825-011 & Present specimen (mm) & Present specimen $\%$ of $\mathrm{HL}$ \\
\hline $\mathrm{TL}(\mathrm{mm})$ & $229-360$ & 287 & 483 & \\
\hline $\mathrm{HL}(\mathrm{mm})$ & $36.6-58.5$ & 50.9 & 85 & \\
\hline SNL $(\% \mathrm{HL})$ & 0.2 & 10.7 & 18.1 & 0.21 \\
\hline ED (\%HL) & 0.2 & 13.8 & 11.4 & 0.13 \\
\hline UJL & 0.5 & 26.7 & 35.1 & 0.41 \\
\hline LJL & 0.6 & 28.6 & 37.9 & 0.45 \\
\hline PDL & $1.1-1.2$ & 57.5 & 70.6 & 0.83 \\
\hline PAL & $1.6-1.7$ & 82.8 & 95.3 & 1.12 \\
\hline STA & $1.6-1.7$ & 81 & 98.7 & 1.16 \\
\hline PL & $0.7-0.8$ & 34.2 & 45.3 & 0.53 \\
\hline $\mathrm{BD}$ & $0.7-0.9$ & 46.7 & 48.2 & 0.57 \\
\hline
\end{tabular}

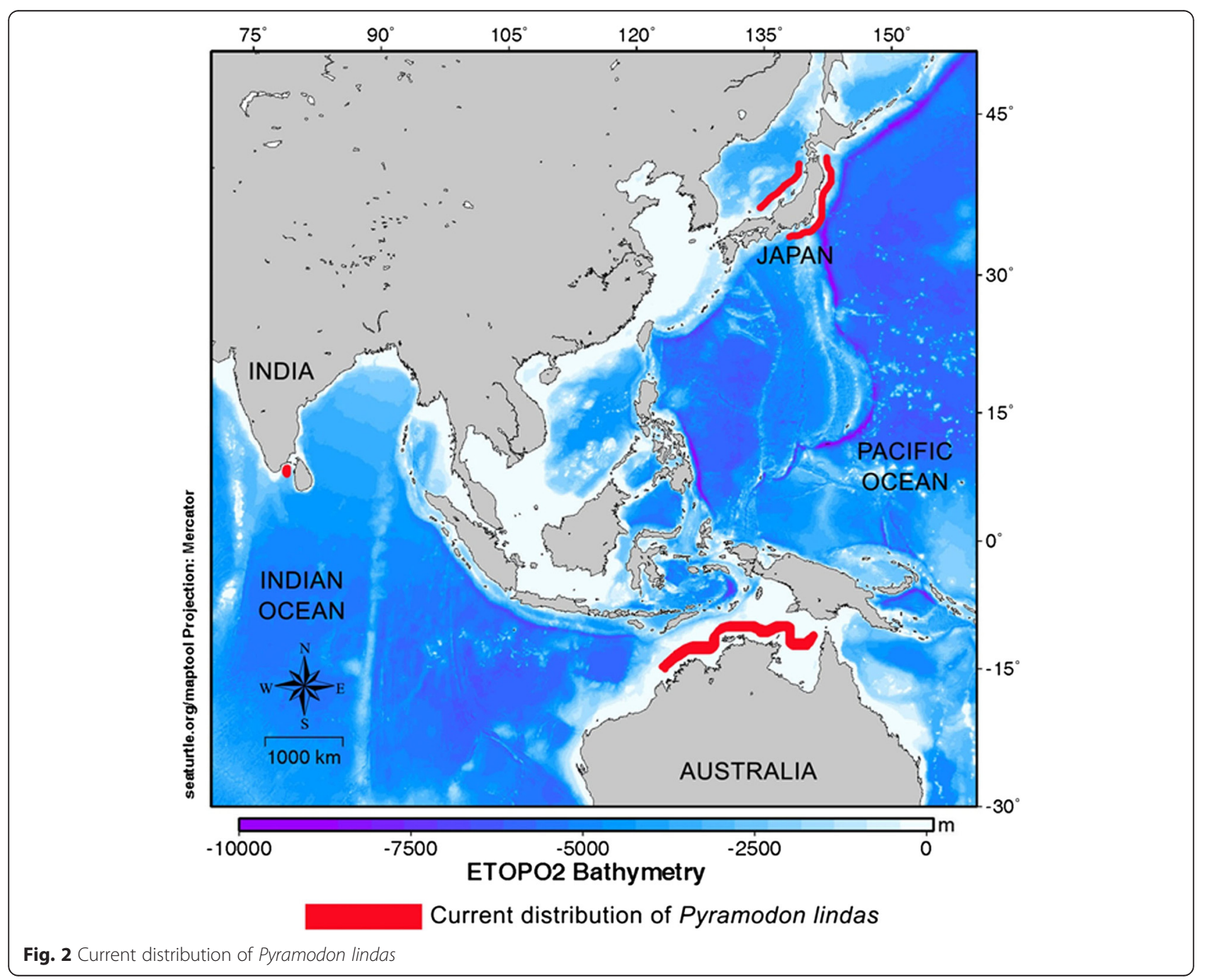




\section{Difference between other species}

Mainly the head and body of Pyramodon lindas are generally unpigmented. Other three species are generally pigmented. These $P$. lindas have $21-25$ pectoral fin rays while others have more than 25 pectoral fin rays compared to other three species pectoral fin length of the Pyramodon lindas is relatively short.

\section{Pyramodon parini}

The size ranges from 169 to $305 \mathrm{~mm}$ in TL. These are the most darkly pigmented in the species. It has paired gonads. The pectoral fin is relatively long. The main distribution area is south eastern pacific.

\section{Pyramodon punctatum}

The size ranges from 62 to $619 \mathrm{~mm}$ in TL. These are moderately pigmented. The pectoral fin is relatively short. The tips of its rays falling $3-10 \mathrm{~mm}$ short of the posterior end of the swim bladder. P. punctatus is a species inhabiting the southern hemisphere, known from off South Africa, south eastern Australia and Newzealand at depths of 120-731 m.

\section{Pyramodon ventralis}

The size ranges from 62 to $564 \mathrm{~mm}$ in TL. These are the most lightly pigmented in the genus and have a generally more delicate appearance than other species of Pyramodon. The pectoral fin is relatively long, extending $8-23$ beyond the posterior end of the swim bladder. Pectoral fin length is also strongly allometric (Markle and Olney, 1981).

\section{Distribution}

Northern Australia, Japan, India. Benthopelagic in 250 to $385 \mathrm{~m}$ and rare species (Fig. 2).

\section{Taxonomic note}

The species Pyramodon lindas is first described by Markle and Olney in 1990. They collected the specimen from North West shelf, Australia, $18^{\circ} 59^{\prime}$ S, $117^{\circ} 10^{\prime}$ E depth 300 $326 \mathrm{~m}$. The holotype of the species is deposited at a museum as a number of AMS1.22825-011. The geographical distribution area of the species is tropical and temperate Indo- Pacific, the habitat is marine, apparently free living at depths of $120-731 \mathrm{~m}$ and the size is $360 \mathrm{~mm}$.

\section{Conclusion}

The Pyramodon lindas reported in the present study makes the total species reported from India as four in family Carapidae. The other earlier reports were Carapus homei (Richardson, 1846), Pyramodon punctatum (Regan, 1914) and Carapus margaritiferae (Rendahl, 1921) (Mahadevan, 1961). The present report on Pyramodon lindas is a new record from the Indian water adding diversity to Indian marine resources.

\section{Acknowledgements}

The authors wish to express their gratitude to the Director, Central Marine Fisheries Research Institute, Cochin and Scientist in Charge (SIC), of Tuticorin Research Centre (TRC) of CMFRI for providing for the facilities and encouragement. Authors also acknowledged to Sajan John for supporting manuscript preparation.

\section{Authors' contributions}

KKJ conceived the study and drafted the manuscript. KK collected, measured the specimens and deposited in the Museum. PUZ, JAJ \& GG participated in the design, coordinated and helped to draft the manuscript. All authors have read and approved the final manuscript.

\section{Competing interests}

The authors declare that they have no competing interests.

\section{Author details}

${ }^{1}$ Central Marine Fisheries Research Institute (CMFRI), Post Box 1603, Ernakulam North P.O., Kochi 682018, Kerala, India. ${ }^{2}$ Tuticorin Research Center (TRC), Central Marine Fisheries Research Institute, (CMFRI), South beach road (near Rochi park), Tuticorin 628 001, Tamil Nadu, India. ${ }^{3}$ Wildlife Institute of India, Chandrabani, Dehradun 248001, India.

Received: 22 April 2016 Accepted: 6 June 2016

Published online: 20 July 2016

\section{References}

Cohen DM, Nielsen JG. Guide to the identification of genera of the fish order Ophidiiformes with a tentative classification of the order. NOAA Technical Report NMFS Circular. 1978;417:1-72.

Gosline WA. Hawaiian lava-flow fishes, Part IV. Snyderidia canina Gilbert, with notes on the osteology of ophidioid fishes. Pac Sci. 1960;14:373-81.

Jordan DS, Fowler HW. A review of the ophidioid fishes of Japan. Proceedings of the United States National Museum v. 1902;25(1303):743-766.

Mahadevan S. The pearl fish Carapus margaritiferae (Rendahl), a new record for the Indian waters. J Mar Biol Ass India. 1961;3(1 \& 2):204-208.

Markle DF, Olney JE. A description of the vexillifer larvae of Pyramodon ventralis and Snyderidia canina (Pisces, Carapidae) with comments on classification. Pac Sci. 1981;34:173-80.

Markle DF, Olney JE. Systematics of the pearlfishes (Pisces: Carapidae). Bull Mar Sci. 1990:47(2):269-410.

Nielsen JG, Cohen DM, Markle DF, Robins CR, FAO Species Catalogue. Vol. 18. Ophidiiform fishes of the world (Order Ophidiiformes). An annotated and illustrated catalogue of pearl fishes, cusk-eels, brotulas and other ophidiiform fishes known to date. Rome: FAO Fisheries Synopsis 125. 1999;18:178.

Regan CT. Diagnoses of new marine fishes collected by the British Antarctic (Terra Nova) expedition. Annals and Magazine of Natural History. 1914;(Series 8) v 13(73):11-17.

Rendahl H. Results of Dr E Mjöbergs Swedish scientific expeditions to Australia, 1910-13, XXVIII. Fische K Sven Vetenskapsakad Handl. 1921;1-24.

Richardson J. Report on the ichthyology of the seas of China and Japan. Report of the British Association for the Advancement of Science 15th meeting held at Cambridge in June, 1845. 1846;187-320.

Robins CR, Nielsen JG. Snyderidia bothrops, a new tropical, amphi-Atlantic species (Pisces: Carapidae). Studies in Tropical. Oceanography. 1970;4:285-93.

Smith HM, Radcliffe L. Descriptions of seven new genera and thirty-one new species of fishes of the families Brotulidae and Carapidae from the Philippine Islands and the Dutch East Indies. Proceedings of US National Museum. 1913; 44:135-176.

Strasburg DW. Description of the larval and familial relationships of the fish Snyderidia canina. Copeia. 1965:20-24.

Trott LB. A general review of the pearl fishes (Pisces, Carapidae). Bull Mar Sci. 1981:31:623-9. 